\title{
Phosphorus nutrition of beech (Fagus sylvatica L.) is decreasing in Europe
}

\author{
Ulrike Talkner • Karl Josef Meiwes • Nenad Potočić • \\ Ivan Seletković • Nathalie Cools • Bruno De Vos • \\ Pasi Rautio
}

Received: 2 June 2014 / Accepted: 13 January 2015 / Published online: 12 March 2015

(C) INRA and Springer-Verlag France 2015

\begin{abstract}
- Key message Foliar phosphorus concentrations have decreased in Europe during the last 20 years. High atmospheric nitrogen deposition and climate change might be responsible for this trend. Continued decrease in foliar $\mathbf{P}$ concentrations might lead to reduced growth and vitality of beech forests in Europe.

- Context Increased forest soil acidification, atmospheric nitrogen deposition, and climate change have been shown to affect phosphorus nutrition of forest trees. Low foliar phosphorus levels and high nitrogen/phosphorus ratios have been observed in different European countries and have been related to reduced growth in forests.

- Aims We test the hypothesis that phosphorus concentrations of European beech (F. sylvatica L.) foliage are decreasing at the European scale.
\end{abstract}

Handling Editor: Thomas Wohlgemuth

Contribution of the co-authors Ulrike Talkner: Analyzing the data, writing the manuscript; Karl Josef Meiwes: Supervising the work; Nenad Potočić: Writing the manuscript; Ivan Seletković: Writing the manuscript; Nathalie Cools: Soil data analyses; Bruno De Vos: Soil data analyses; Pasi Rautio: Writing the manuscript.

U. Talkner $(\bowtie) \cdot$ K. J. Meiwes

Northwest German Forest Research Station, Grätzelstr. 2,

37079 Göttingen, Germany

e-mail: ulrike.talkner@nw-fva.de

K. J. Meiwes

e-mail: karl-josef.meiwes@nw-fva.de

N. Potočić • I. Seletković

Croatian Forest Research Institute, Cvjetno naselje 41,

10450 Jastrebarsko, Croatia

N. Potočić

e-mail: nenadp@sumins.hr

I. Seletković

e-mail: ivans@sumins.hr
- Methods Foliar phosphorus concentrations in beech were monitored on the basis of the "International Co-operative Programme on Assessment and Monitoring of Air Pollution Effects on Forests." Here, data from 12 European countries, comprising 79 plots and a 20-year sampling period (19912010), were evaluated.

- Results Foliar phosphorus concentrations ranged from 0.81 to $1.66 \mathrm{mg} \mathrm{g}^{-1} \mathrm{dw}$ (plot median of the 20 -year sampling period). On $22 \%$ of the plots, phosphorus concentrations were in the deficiency range of beech (Mellert and Göttlein 2012). On $62 \%$ of the plots, the nitrogen/phosphorus ratio was above 18.9, which is considered to be disharmonious for beech. In addition, foliar phosphorus concentrations were significantly decreasing by, on average, $13 \%$ from 1.31 to $1.14 \mathrm{mg} \mathrm{g}^{-1}$ in Europe $(p<0.001)$.

- Conclusion Our results show that phosphorus nutrition of beech is impaired in Europe. Possible drivers of this development might be high atmospheric nitrogen deposition and climate change. Continued decrease in foliar phosphorus concentrations, eventually attaining phosphorus deficiency levels,

\footnotetext{
N. Cools

Research Institute for Nature and Forest, Gaverstraat 4,

9500 Geraardsbergen, Belgium

e-mail: nathalie.cools@inbo.be
}

B. De Vos

Research Institute for Nature and Forest, Gaverstraat 4, 9500 Geraardsbergen, Belgium

e-mail: bruno.devos@inbo.be

P. Rautio

Natural Resources Institute Finland, Northern Unit, P.O. Box 16, 96301 Rovaniemi, Finland

e-mail: pasi.rautio@luke.fi 
might lead to reduced growth and vitality of beech forests in Europe.

Keywords Forest foliar nutrition - Temporal trend . Phosphorus deficiency $\cdot$ Forest monitoring $\cdot$ N/P ratio

\section{Introduction}

Phosphorus $(\mathrm{P})$ plays a key role in many plant processes such as energy metabolism, synthesis of nucleic acids and membranes, photosynthesis, respiration, nitrogen fixation, and enzyme regulation (Raghothama 1999). Nitrogen $(\mathrm{N})$ and $\mathrm{P}$ are the most frequently limiting macronutrients for primary production (Vitousek et al. 2010) and $\mathrm{P}$ deficiency in plants leads to reduced growth and reproduction (Mengel and Kirkby 1982). Foliar P concentrations are a good indicator for the plant availability of $\mathrm{P}$ at a site, since up to now, no single extraction method is capable to quantify plant-available $\mathrm{P}$ in soils adequately.

Increased forest soil acidification, atmospheric $\mathrm{N}$ deposition, and climate change (increasing temperature and $\mathrm{CO}_{2}$ levels) have been shown to affect $\mathrm{P}$ nutrition of forest trees (Aber 1992; Duquesnay et al. 2000; Gradowski and Thomas 2006, 2008; Prietzel and Stetter 2010). Low foliar $\mathrm{P}$ concentrations and high N/P ratios are in turn related to reduced growth in forest stands (Braun et al. 2010; Prietzel and Stetter 2010; Trichet et al. 2009; Wardle et al. 2004). Reduced forest growth might be the consequence of reduced leaf size and total leaf area, which was found to be the response to low P supply in white birch (Danyagari and Dang 2014). P deficiencies, decreasing foliar $\mathrm{P}$ levels, or high N/P ratios have been reported for beech forests in Switzerland (Braun et al. 2010), France, Belgium, and Luxemburg (Jonard et al. 2009). However, many questions concerning forest P nutrition are still unexplained. One major question concerns decreasing foliar $\mathrm{P}$ concentrations and possible $\mathrm{P}$ deficiency: Are decreasing foliar $\mathrm{P}$ concentrations a local or a more widespread phenomenon?

To answer this question, the present data evaluation tests the hypothesis that $\mathrm{P}$ concentrations in European beech (Fagus sylvatica L.) foliage are decreasing at European scale. As a part of the cooperative program of UNECE and EC, ICP Forests (International Co-operative Programme on Assessment and Monitoring of Air Pollution Effects on Forests), foliar nutrient concentrations of forest trees have been monitored in Europe since the early 1990 s, enabling us to evaluate a unique, harmonized dataset of foliar P concentrations of beech.

\section{Material and methods}

\subsection{Foliage sampling and analyses}

Foliage sampling was carried out on ICP Forests Level II plots. The Level II plots are part of ICP Forests intensive monitoring sites that have been selected by member countries to represent typical managed (beech) forests in a particular area. Selection has followed the guidelines described in the ICP Forests manual (Ferretti et al. 2010). On each sample plot, the sample tree selection and sampling were carried out following the manual of ICP Forests (Rautio et al. 2010; Rautio and Fürst 2013). According to the manual, a minimum of five sample trees was randomly selected among the dominant and predominant trees. The same sample trees were used over the years, except in case where the trees had small crown and foliage mass. In this case, alternating sampling of two sets of sample trees was done to avoid excess damage to the crown.

In most of the plots, sampling was performed biannually every uneven year. Sampling was done during the second half of the growing season before the onset of autumnal yellowing. Only mature leaves grown in full sun were collected from the upper third of the crown. Collected foliar samples were kept dark and cool during the transportation and during storage in laboratory prior to pretreatment. Before drying, leaves were detached from twigs, and a composite sample was made by mixing equal amounts of leaves from individual sample trees of the same plot. Samples were dried at a maximum of $70{ }^{\circ} \mathrm{C}$ for at least $24 \mathrm{~h}$, after which they were ground to a fine homogeneous powder.

Most of the laboratories analyzing foliar samples in the ICP Forests program use the recommended procedures for digestion (or ashing) and analytical determination described in the ICP Forests manual (Rautio et al. 2010; Rautio and Fürst 2013). Recommended methods for digestion/ashing before $\mathrm{P}$ determination are microwave pressure digestion (closed system with nitric acid or nitric acid mixtures), wet ashing at room pressure (open system with nitric acid or nitric acid mixtures), and pressure digestion (closed system with nitric acid or nitric acid mixtures); in the case of the X-ray fluorescence method (pelleting), there is no pretreatment needed. For P determination, the recommended methods are inductively coupled plasmaatomic emission spectroscopy (ICP-AES), visible photometry, and X-ray fluorescence. For $\mathrm{Ca}, \mathrm{K}$, and $\mathrm{Mg}$ determination, ICP-AES, flame atomic absorption spectroscopy (AAS), and X-ray fluorescence methods are recommended. In case other methods are used, they need to be validated by taking part in the annual needle/leaf interlaboratory comparison tests organized by the Forest Foliar Coordinating Centre of ICP Forests (Fürst 2014). Every laboratory analyzing ICP Forests foliage samples is obliged to take part in these interlaboratory comparison tests and has to have 
acceptable results to pass the tests. Tolerable limits to pass the tests vary depending on the analyzed elements (see details in Fürst 2014 and Rautio et al. 2010). Furthermore, each participating laboratory needs to follow strict quality assurance procedures (use of control charts, results within plausible ranges, etc.) before they can submit data to the ICP Forests database (see details for the quality assurance procedures in König et al. 2010).

Data of the 20-year sampling period from 1991 to 2010 were taken into consideration. Only plots with five or more sampling years were chosen for statistical analyses. This resulted in a dataset comprising foliar $\mathrm{P}$ concentrations of 40 160 year old beech stands from 12 countries ( 79 plots in total), covering a large latitudinal (from Denmark at $56^{\circ} \mathrm{N}$ to Italy at $38^{\circ} \mathrm{N}$ ) and longitudinal (from Spain at $3^{\circ} \mathrm{W}$ to Slovak Republic at $22^{\circ} \mathrm{E}$ ) range (Fig. 1 and Table 1). The main distribution area of beech is Central and Eastern Europe; in
Southern and Northern Europe, beech is still occurring but less frequently. Hence, the plots span the main distribution area of beech, with Eastern Europe being underrepresented.

The foliar nutrient concentrations were evaluated according to the classification system of van den Burg, which was compiled and evaluated by Mellert and Göttlein (2012). For P, deficiency starts at foliar concentrations $<1.07 \mathrm{mg} \mathrm{g}^{-1}$, which is similar to the lowest class (foliar $\mathrm{P}<1 \mathrm{mg} \mathrm{g}^{-1}$ ) in the classification system that was established and agreed on for European ICP Forests assessments (Stefan et al. 1997).

\subsection{Soil sampling and analyses}

Within each level II plot, forest floor samples were taken at three representative locations and mineral soil subsamples on at least 24 locations. In the beech forest floors, $\mathrm{OL}, \mathrm{OF}$, and $\mathrm{OH}$ sublayers were distinguished. If $\mathrm{OH}$ layers were $<1 \mathrm{~cm}$ thick,

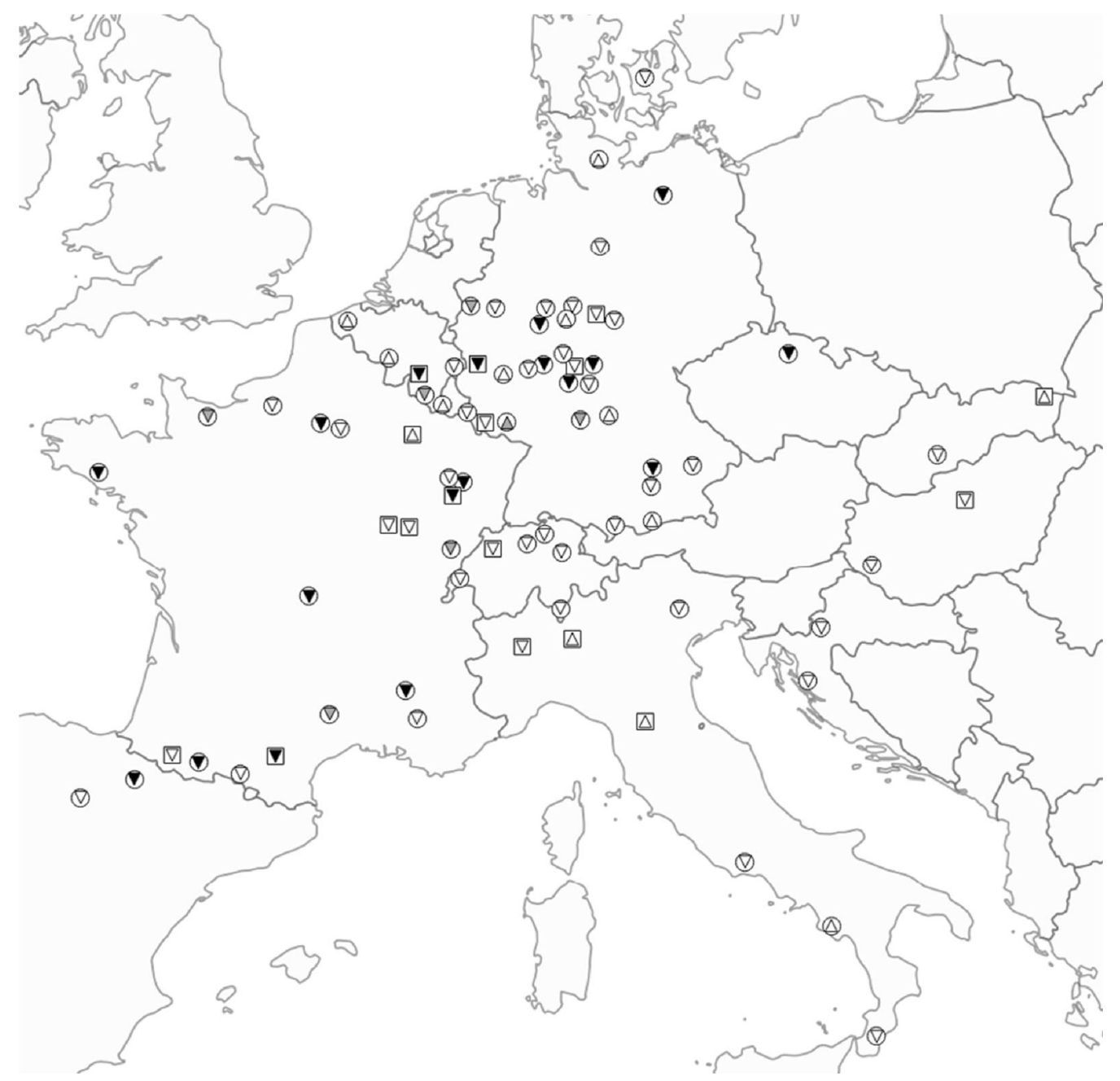

Fig. 1 Foliar P levels and trends on 79 beech plots in Europe. Foliar P concentrations (plot median over the whole 20-year period) were in the normal or the latent deficiency range on 62 plots (circles foliar $P \geq 1.07 \mathrm{mg} \mathrm{g}^{-1}$ ) according to the classification system of van den Burg (Mellert and Göttlein 2012) and in the deficiency range on 17 plots (squares foliar $P<1.07 \mathrm{mg} \mathrm{g}^{-1}$ ). Foliar $\mathrm{P}$ concentrations decreased (downwarded triangles) on 65 plots and increased (upwarded triangles) on 14 plots during the 20 -year observation period (black triangles $p<0.05$; gray triangles $0.05<p<0.1$; white triangles $p>0.1$ 
Table 1 List of countries, number of plots per country with five or more sampling years and with less than five sampling years, and regional classification of the plots of each country

\begin{tabular}{|c|c|c|c|}
\hline \multirow[t]{2}{*}{ Country } & \multicolumn{2}{|c|}{ Number of plots } & \multirow[t]{2}{*}{ Region } \\
\hline & $\geq 5$ years & $<5$ years & \\
\hline Austria & 0 & 1 & $\mathrm{EE}$ \\
\hline Belgium & 5 & 3 & $\mathrm{CE}$ \\
\hline Bulgaria & 0 & 1 & SE \\
\hline Croatia & 2 & 0 & SE \\
\hline Czech Republic & 1 & 2 & $\mathrm{EE}$ \\
\hline Denmark & 1 & 4 & $\mathrm{NE}$ \\
\hline France & 20 & 0 & CE, SE \\
\hline Germany & 29 & 11 & $\mathrm{CE}$ \\
\hline Hungary & 2 & 1 & $\mathrm{EE}$ \\
\hline Italy & 7 & 3 & SE, CE \\
\hline Luxembourg & 2 & 0 & $\mathrm{CE}$ \\
\hline Poland & 0 & 11 & $\mathrm{EE}$ \\
\hline Romania & 0 & 2 & SE \\
\hline Slovak Republic & 2 & 1 & $\mathrm{EE}$ \\
\hline Slovenia & 0 & 5 & SE, EE \\
\hline Spain & 2 & 1 & SE \\
\hline Sweden & 0 & 9 & $\mathrm{NE}$ \\
\hline Switzerland & 6 & 1 & $\mathrm{CE}$ \\
\hline UK & 0 & 8 & $\mathrm{CE}, \mathrm{NE}$ \\
\hline
\end{tabular}

The countries with at least one plot with five or more sampling years have been selected for statistical analyses and are typed in italics. Every plot was classified into one of the four regions Central, Eastern, Northern, and Southern Europe according to its coordinates; countries may have plots in several regions

they were combined with OF to OFH layers. In this study, the analytical results of combined $\mathrm{OF}$ and $\mathrm{OH}$ layers $(\mathrm{OFH})$ were used, computed as mass weighted averages. Relative to the top of the mineral soil (zero depth), four fixed depth increments were sampled: $0-10 \mathrm{~cm}, 10-20 \mathrm{~cm}, 20-40 \mathrm{~cm}$, and $40-80 \mathrm{~cm}$. The subsamples were combined by depth layer in three spatially clustered samples and analyzed separately. In this study, the average values of the three composites are used. The physical and chemical properties of the forest floor and mineral soil samples were assessed according to the methods outlined in the ICP Forests manual (Cools and De Vos 2013).

Soil reaction $(\mathrm{pH})$ was measured in a 1:5 $(v / v)$ suspension in a $0.01 \mathrm{M} \mathrm{CaCl}_{2}\left(\mathrm{pH}-\mathrm{CaCl}_{2}\right)$ extract following ISO 10390. Total organic $\mathrm{C}$ was determined by dry combustion using a total analyzer according to ISO 10694. Total nitrogen was quantified by the modified Kjeldahl method (ISO 11261) or by total analyzer (ISO 13878). Total P in soil was determined by ICP-AES or by colorimetry in an aqua regia extract after reflux digestion. Exchangeable cations were determined in a $0.1 \mathrm{M} \mathrm{BaCl}_{2}$ solution after single extraction, modified from ISO 11260. Base saturation was computed as the sum of exchangeable $\mathrm{Ca}, \mathrm{Mg}$, $\mathrm{K}$, and $\mathrm{Na}$ over all these cations including $\mathrm{Al}, \mathrm{Fe}, \mathrm{Mn}$, and free $\mathrm{H}^{+}$. Quality assurance of the results was assured by biannual interlaboratory comparisons (Cools et al. 2006, 2007).

Humus form description was based on the proposed European classification (Zanella et al. 2006, 2011). On the study plots, four main humus forms were distinguished: mull, moder, mor, and amphihumus (FSCC 2006).

\subsection{Statistical analyses}

Single linear regressions were computed to analyze the temporal trend in foliar $\mathrm{P}, \mathrm{K}, \mathrm{Ca}$, and $\mathrm{Mg}$ concentrations of each plot separately (foliar P: Fig. 1), and a linear mixed effects model with "plot" as random effect was used to analyze the common temporal trend of the selected beech plots (Pinheiro et al. 2013) (foliar P: Fig. 2). The model was run with and without the fixed effect "tree age class," a categorical variable classifying the plots according to their age. Since the tree age had no significant effect on the trend in foliar P concentrations, the model without tree age is presented and discussed further.

Single linear regressions were calculated to analyze the relationship between the foliar P concentrations or the temporal trend in foliar $\mathrm{P}$ concentrations and the $\mathrm{pH}$, base saturation, total $\mathrm{P}$ content, $\mathrm{C} / \mathrm{P}$ ratio, and N/P ratio of the forest floor (if available) and the mineral soil. With the exception that a correlation analysis was done to analyze the correlation between the foliar $\mathrm{P}$ concentrations and the total $\mathrm{P}$ content of the forest floor because foliar $\mathrm{P}$ concentrations likely determine the $\mathrm{P}$ content of the forest floor, making a regression analysis inappropriate. Differences in the foliar P concentrations or the temporal trend in foliar $\mathrm{P}$ concentrations between the humus types were tested with an analysis of variance (ANOVA) and subsequent multiple comparisons of the parameters of the ANOVA (Hothorn et al. 2008; Zeileis 2004).

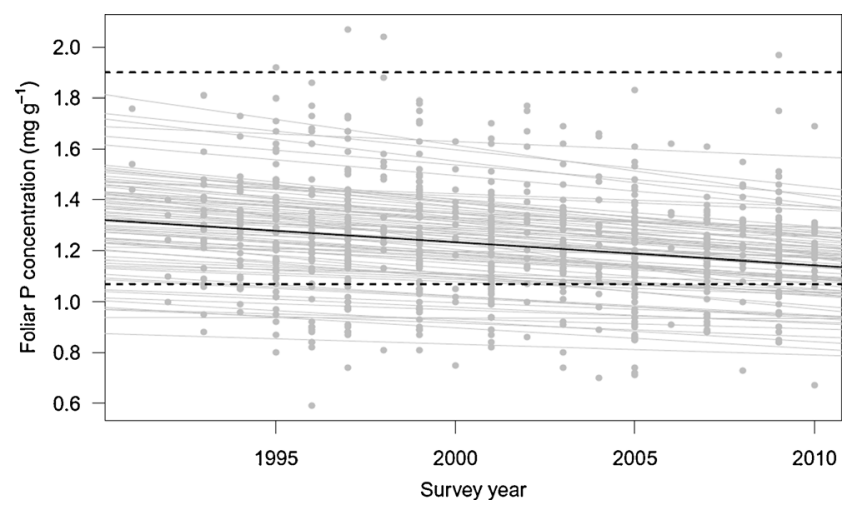

Fig. 2 Trends in foliar P concentrations on individual plots (gray lines) and the negative common trend (thick black line). The values for low (lower dashed line) and high (upper dashed line) foliar P concentrations (Mellert and Göttlein 2012) are also indicated for a reference. The panEuropean trend was significant at $p<0.001$ (linear mixed effects model: $y=-0.009 x+1.312$; in the model $x=0$ is in the year 1991) 
All statistical analyses were made with $\mathrm{R}$ version 3.0.2 ( $\mathrm{R}$ Core Team 2013). The R packages "nlme" (Pinheiro et al. 2013), "multcomp" (Hothorn et al. 2008), and "sandwich" (Zeileis 2004) were used.

\section{Results}

Even though foliar P concentrations differed between sample plots across Europe, the coefficient of variation was quite low (18\%). The foliar P concentrations ranged from 0.81 to $1.66 \mathrm{mg} \mathrm{g}^{-1} \mathrm{dw}$ (plot median over the whole period). On $22 \%$ of the plots, foliar P concentrations (plot median) were deficient (Mellert and Göttlein 2012): 17 out of 79 plots had foliar P concentrations $<1.07 \mathrm{mg} \mathrm{g}^{-1} \mathrm{dw}$ (Fig. 1). No plots with surplus foliar P concentrations (plot median, $>1.9 \mathrm{mg} \mathrm{g}^{-1}$ ) were found. The N/P ratio ranged from 16 to 30 (plot median), with $62 \%$ of the plots having ratios higher than 18.9, which is considered the upper level for harmonious nutrition of beech by Mellert and Göttlein (2012). Foliar P concentrations did not differ among regions $(p=0.951)$. The plots were classified into regions (Central, Southern, Eastern, and Northern Europe) according to their coordinates.

We found foliar $\mathrm{P}$ concentrations of beech trees to be significantly decreasing in Europe $(p<0.001$; Fig. 2$)$ and foliar $\mathrm{N} / \mathrm{P}$ ratios to be significantly increasing $(p<0.001$; Fig. 3$)$. This trend was not affected by the age of the trees. The results of the linear mixed effects model show that, during the 20year long observation period (1991-2010), foliar P concentrations decreased by $-13 \%$ from 1.31 to $1.14 \mathrm{mg} \mathrm{g}^{-1}$. When looking at individual plots (linear regressions computed separately for each plot), the results show that foliar P concentrations were decreasing on 65 plots (up to $-50 \%$ ) and increasing on 14 plots (up to $+14 \%$ ). All increases were insignificant

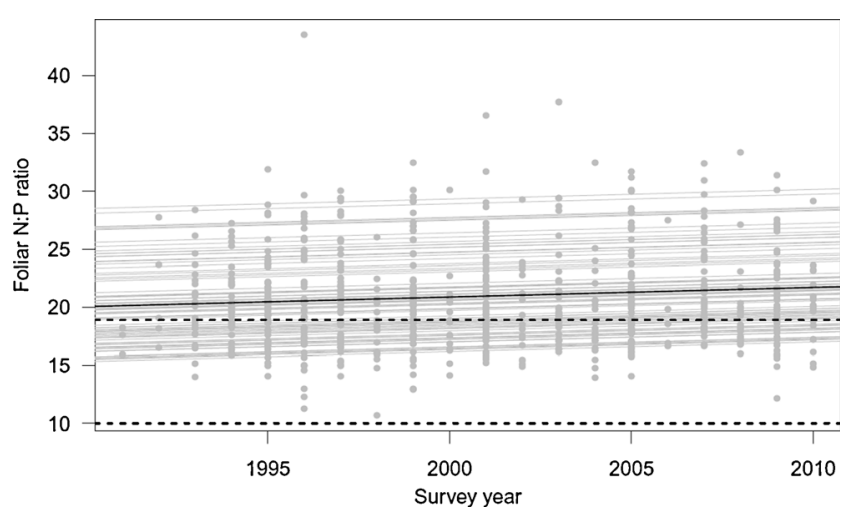

Fig. 3 Trends in foliar N/P ratio on individual plots (gray lines) and the positive common trend (thick black line). The range of harmonious N/P ratios (dashed lines) is indicated for a reference (Mellert and Göttlein 2012). The common trend was significant at $p<0.001$ (linear mixed effects model: $y=0.083 x+20.131$; in the model $x=0$ is in the year 1991)

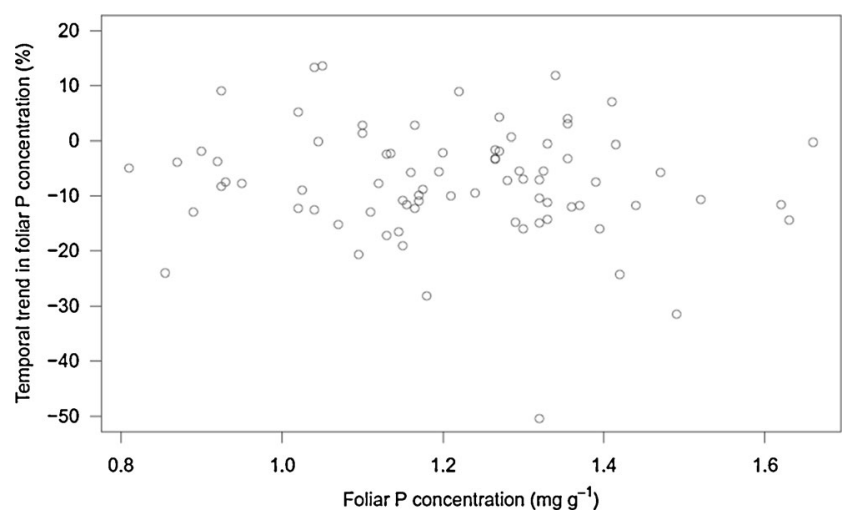

Fig. 4 Single linear regression between the trend in foliar $\mathrm{P}$ concentration and the foliar $\mathrm{P}$ concentration showed no significant relationship $(p>0.05)$

$(p>0.05)$, whereas the decreases were significant $(p<0.05)$ for 18 plots. When excluding these 18 plots and just evaluating the plots showing insignificant increases and insignificant decreases with the linear mixed effects model, still a significant $(p<0.001)$ pan-European decrease in foliar $\mathrm{P}$ concentrations of $-8 \%$ (from 1.29 to $1.18 \mathrm{mg} \mathrm{g}^{-1}$ ) was detected. The trend in foliar $\mathrm{P}$ concentration was not related to the median foliar $\mathrm{P}$ concentration; hence, not only plots with adequate foliar $\mathrm{P}$ concentrations had negative trends but plots with deficient foliar P concentrations, too (Fig. 4).

In addition to foliar $\mathrm{P}$ concentrations, foliar $\mathrm{Ca}$ and $\mathrm{Mg}$ concentrations significantly decreased during the 20-year observation period, considering the same 79 plots, while foliar K concentrations did not decrease significantly. On all plots foliar $\mathrm{K}$ nutrition could be evaluated as good. Foliar $\mathrm{Ca}$ nutrition was on $38 \%$ of the plots and foliar Mg nutrition on $37 \%$ of the plots in the latent deficiency range (Mellert and Göttlein 2012).

Foliar P data were compared with several forest floor and mineral soil parameters: humus type, $\mathrm{pH}\left(\mathrm{CaCl}_{2}\right)$, base saturation (BS), total $\mathrm{P}$ content $(\mathrm{P}), \mathrm{C} / \mathrm{P}$, and $\mathrm{N} / \mathrm{P}$ ratio. The plots differed in their soil chemical characteristics (Table 2).

The trend in foliar P concentration was not significantly correlated with $\mathrm{pH}$, base saturation, total $\mathrm{P}$ content, and the $\mathrm{C} / \mathrm{P}$ and $\mathrm{N} / \mathrm{P}$ ratios. Even though there was no significant correlation between the temporal trend and the $\mathrm{pH}$, it was obvious that the plots with significantly decreasing foliar $\mathrm{P}$ concentrations did not solely have soils with particularly low $\mathrm{pH}$ values. The $\mathrm{P}$ content and the $\mathrm{C} / \mathrm{P}$ and $\mathrm{N} / \mathrm{P}$ ratios of the litter layer were not correlated with the trend in foliar $\mathrm{P}$ concentration nor had the humus type an effect on the trend in foliar P concentration. Foliar P concentrations were higher on plots with lower $\mathrm{pH}$ values in $0-10-\mathrm{cm}$ soil depth (Fig. 5). In other soil depths, the relationship was also negative, but insignificant. Foliar P concentrations were positively correlated with the $\mathrm{P}$ content (Fig. 6) and negatively with the $\mathrm{C} / \mathrm{P}$ ratio 
Table 2 Cation exchange capacity (CEC), base saturation (BS), pH, organic carbon content (C), total nitrogen content (N), and aqua regia extractable $\mathrm{P}$ content $(\mathrm{P})$ in the litter layer and different mineral soil depths of the 79 plots

\begin{tabular}{|c|c|c|c|c|c|c|c|c|c|c|c|c|c|c|c|c|c|c|c|c|c|c|c|c|c|}
\hline & \multicolumn{5}{|c|}{$\mathrm{pH}\left(\mathrm{CaCl}_{2}\right)$} & \multicolumn{5}{|c|}{ BS (\%) } & \multicolumn{5}{|c|}{$\mathrm{C}\left(\mathrm{g} \mathrm{kg}^{-1}\right)$} & \multicolumn{5}{|c|}{$\mathrm{N}\left(\mathrm{g} \mathrm{kg}^{-1}\right)$} & \multicolumn{5}{|c|}{$\mathrm{P}\left(\mathrm{mg} \mathrm{kg}^{-1}\right)$} \\
\hline & MV & & SD & Min & Max & MV & & SD & Min & Max & MV & & SD & Min & Max & MV & & SD & Min & Max & MV & & $\mathrm{SD}$ & Min & Max \\
\hline Litter layer & 3.7 & \pm & 3.4 & $(2.7$ & 5.9) & 82 & \pm & 16 & $(44$ & 99) & 407 & \pm & 58 & $(228$ & 488) & 16.3 & \pm & 3.0 & $(8.6$ & 22.8) & 966 & \pm & 286 & $(447$ & 1608) \\
\hline $0-10 \mathrm{~cm}$ & 3.5 & \pm & 3.3 & $(2.6$ & 7.0) & 45 & \pm & 34 & $(6$ & 100) & 60 & \pm & 42 & (19 & 195) & 3.6 & \pm & 2.4 & $(1.1$ & 10.7) & 512 & \pm & 308 & $(52$ & 1487) \\
\hline $10-20 \mathrm{~cm}$ & 3.9 & \pm & 3.8 & $(3.0$ & 7.4) & 38 & \pm & 36 & $(3$ & 100) & 31 & \pm & 27 & (6 & 111) & 2.0 & \pm & 1.6 & $(0.5$ & 6.9) & 422 & \pm & 313 & $(68$ & 1482) \\
\hline $20-40 \mathrm{~cm}$ & 4.1 & \pm & 4.1 & $(3.3$ & 7.5) & 43 & \pm & 37 & $(3$ & 100) & 21 & \pm & 19 & (4 & 65) & 1.4 & \pm & 1.2 & $(0.3$ & 5.7) & 395 & \pm & 315 & $(81$ & 1534) \\
\hline $40-80 \mathrm{~cm}$ & 4.2 & \pm & 4.2 & $(3.6$ & 7.3) & 52 & \pm & 40 & $(4$ & 100) & 9 & \pm & 11 & (1 & 44) & 0.7 & \pm & 0.7 & $(0.1)$ & (3.1) & 399 & \pm & 355 & (76 & 1719) \\
\hline
\end{tabular}

Minimum values (Min), mean values (MV), standard deviations (SD), and maximum values (Max) are given

of the litter layer. This correlation diminished in the mineral soil. Furthermore, foliar $\mathrm{P}$ concentration and foliar N/P ratio were significantly correlated with the $\mathrm{N} / \mathrm{P}$ ratio of the forest floor and the mineral soil (Fig. 7), while they were not significantly correlated with the $\mathrm{N}$ content of the forest floor and the mineral soil. The humus type did not have an effect on foliar $\mathrm{P}$ concentrations.

\section{Discussion}

An ongoing deterioration of beech $\mathrm{P}$ nutrition in European forests is definitely taking place: The evaluation of the dataset shows a clear decreasing trend in $\mathrm{P}$ concentrations. This is in accordance with the findings of some earlier national case studies carried out in Western and Central Europe (Braun et al. 2010; Jonard et al. 2009). Even though plots in Eastern Europe are underrepresented in this study, it can be stated that foliar P concentrations decreased also in these countries (Fig. 1) and that there were no statistically significant differences in foliar $\mathrm{P}$ concentrations among the regions. The deterioration of beech $\mathrm{P}$ nutrition is obvious not only from the negative trend but also from the share of beech plots $(62 \%)$ with disharmonious N/P ratios ( $>18.9)$ and the fact that we did

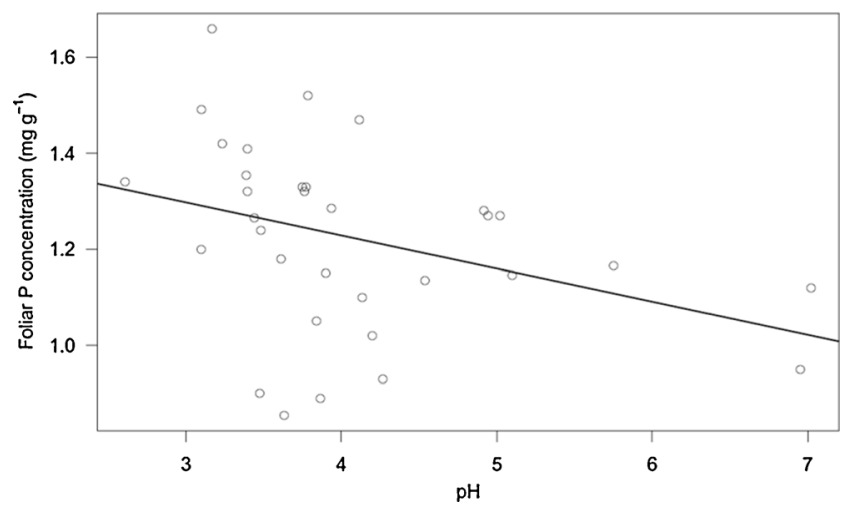

Fig. 5 Single linear regression between foliar $\mathrm{P}$ concentration and $\mathrm{pH}$ $\left(\mathrm{CaCl}_{2}\right)$ in $0-10 \mathrm{~cm}$ soil depth $\left(y=-0.07 x+1.50, p=0.0409, R^{2}=0.13\right)$ not find any plots with high $\mathrm{P}$ concentrations (plot median over the whole period, $>1.9 \mathrm{mg} \mathrm{g}^{-1}$ ) in the sample. Interestingly, foliar P concentrations were not only decreasing on plots with adequate foliar $\mathrm{P}$ concentrations but also on plots with deficient foliar P concentrations (Fig. 4). The evaluation of Europe-wide foliar data in 1995, based on samples collected from ICP Forests extensive monitoring plots (Stefan et al. 1997), revealed that the share of beech plots with N/P ratios above 25 was only $5.7 \%$ (in the present study, $20 \%$ ) and the share of beech plots with high foliar $\mathrm{P}$ concentrations $\left(>1.7 \mathrm{mg} \mathrm{g}^{-1}\right.$ ) was $14 \%$ (in the present study, $0 \%$ ).

Decreasing foliar $\mathrm{P}$ concentrations in forests may develop due to several reasons. Increased $\mathrm{N}$ deposition during the last decades (Galloway 2001) balanced out the growth limitation by $\mathrm{N}$ in many temperate forests (Nihlgård 1985), which eventually became $\mathrm{N}$ saturated (Aber et al. 1998). The improved $\mathrm{N}$ nutrition initially led to increased forest growth (Braun et al. 1999; Högberg et al. 2006; Spiecker 1999), but might also have provoked nutrient imbalances (Aber et al. 1998) including $\mathrm{P}$ deficiency (Flückiger and Braun 1998; Mellert et al. 2004; Mohren et al. 1986). In N-saturated forests, a shift from $\mathrm{N}$ to $\mathrm{P}$ limitation of forest growth has already been observed (Braun et al. 2010; Gradowski and Thomas 2006; Peñuelas et al. 2013) and may be due to several processes. Firstly, excess $\mathrm{N}$ in soils is known to inhibit mycorrhizal growth (Nilsson and Wallander 2003) and to result in a shift in the microbial community structure (Waldrop et al. 2004). This, in turn, may influence $P$ acquisition by plants since mycorrhizal symbioses are an important factor for P uptake by trees (Jansa et al. 2011). Secondly, $\mathrm{N}$ deposition is known to impair soil organic matter decomposition. Peñuelas et al. (2013) state that negative effects of deposited $\mathrm{NH}_{4}$ on litter decomposition, as frequently observed in northern ecosystems, could slow down nutrient cycling and further reduce phosphorus availability and ecosystem productivity. Thirdly, deposition of $\mathrm{N}$ and other acidifying substances also directly influences $\mathrm{P}$ availability to plants by 

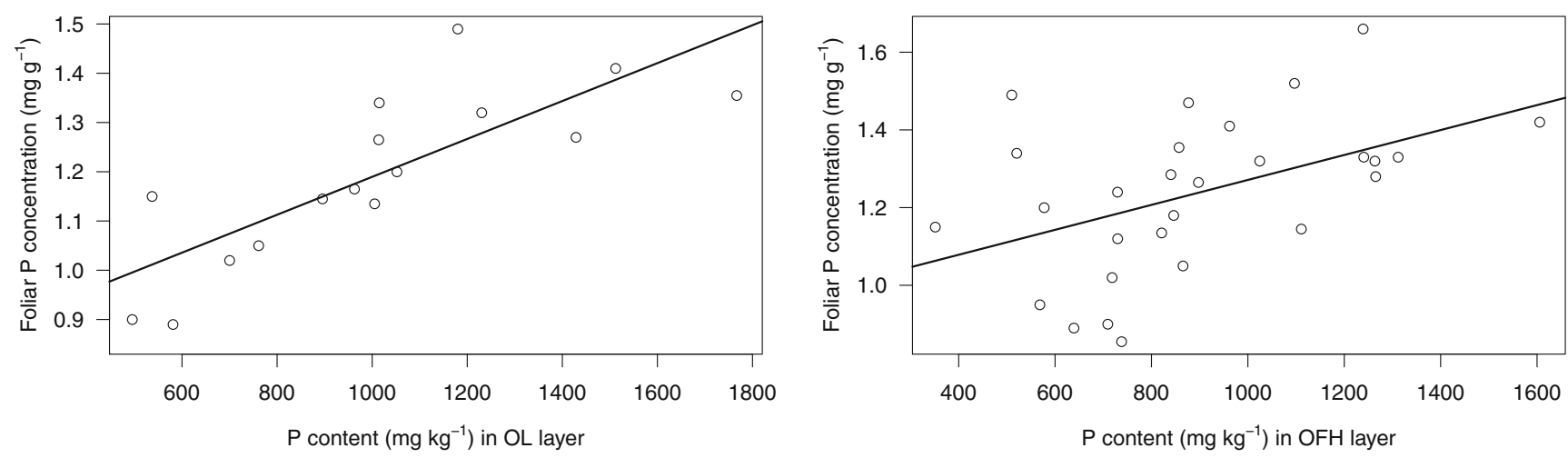

Fig. 6 Correlation between foliar $\mathrm{P}$ concentration and $\mathrm{P}$ content of the forest floor (OL: $p=0.0002053, R=0.80$; OFH: $p=0.01212, R=0.47$ )

increased phosphate adsorption and high soil solution aluminum concentrations in acidified soils (Asp et al. 1991; Haynes 1982). Even though the amount of acid deposition has been substantially reduced in Europe, many forest ecosystems still suffer from soil acidification (Lorenz and Granke 2009) and probably lower P availability.

The significant decrease in foliar $\mathrm{Ca}$ and $\mathrm{Mg}$ concentrations on ICP Forests plots is probably the result of past and ongoing soil acidification and base cation leaching. However, soil acidification is most likely not the only reason for the negative trend in foliar P concentrations seen here because plots with significant decreases in foliar P concentrations were not particularly acidic. Since the N/P ratio of the soil did not explain the variance in the temporal trend, $\mathrm{N}$ deposition was probably not the main reason for the differences in the trend. In contrast, the differences in foliar $\mathrm{P}$ concentrations among the plots were well explained by the N/P ratio of the forest floor and the mineral soil (Fig. 7). Since no correlation between foliar $P$ concentrations and total mineral soil $\mathrm{N}$ or $\mathrm{P}$ was found, the relationship between $\mathrm{N}$ and $\mathrm{P}$ in the soil seems to be of importance for $\mathrm{P}$ nutrition and not the level of the nutrients alone. In addition, the $\mathrm{P}$ nutrition was more balanced with regard to the foliar N/P ratio when the soil N/P ratio was small. The negative correlation between foliar $\mathrm{P}$ concentration and $\mathrm{pH}$ in 0-10 cm soil depth (Fig. 5) did not support the assumption that $\mathrm{P}$ acquisition is impaired due to soil acidification. However, the negative relationship was insignificant in deeper soil layers. Foliar P concentrations were tightly correlated with P contents of the OL layer (Fig. 6). Foliar P concentrations determine the $\mathrm{P}$ content of the litter layer; hence, a strong correlation between $\mathrm{P}$ concentrations in living and senesced leaves is a general pattern, even if there is some variation in $\mathrm{P}$ retranslocation efficiency. The positive correlation is still visible in the combined OF and $\mathrm{OH}$ layer, but fades away with increasing soil depth.

Besides the direct and indirect effects of $\mathrm{N}$ and other acidifying deposition, climate change effects, such as elevated temperatures (De Vries et al. 2000) and drought events (Peuke and Rennenberg 2004), might influence P uptake by plants. Photosynthesis is dependent on sufficient foliar $\mathrm{P}$ levels and may be impaired due to $\mathrm{P}$ deficiency (Reich et al. 2009) especially under elevated atmospheric $\mathrm{CO}_{2}$ concentrations (Conroy et al. 1986). Elevated atmospheric $\mathrm{CO}_{2}$ concentrations as well as increased temperature seem to increase the $\mathrm{C} / \mathrm{P}$ ratio of plants, while the effect of drought is still unclear (Sardans et al. 2011). In addition, the growing season was found to be extended in Europe (Menzel and Fabian 1999) leading to higher photosynthetic activity (Tucker et al. 2001). The rise in temperature and extended growing season combined with higher $\mathrm{N}$ deposition led to increased forest growth (Pretzsch et al. 2014), which might also induce P imbalances.

Internal functions of trees, which in turn are influenced by climate parameters and $\mathrm{N}$ deposition, might also cause $\mathrm{P}$ deficiency in foliage. For example, autumnal withdrawal of $\mathrm{P}$ is significantly reduced at high $\mathrm{N}$ deposition levels (Braun and Flückiger 2013). Furthermore, increased fructification is $P$ demanding and may deplete $\mathrm{P}$ reserves in trees (Jonard et al. 2009; Khanna et al. 2009). Last decennia, masting of beech occurred at shorter intervals in Europe, and masting events were found to be linked to climate parameters (Övergaard et al. 2007; Piovesan and Adams 2001).

Whatever the underlying reason to the observed phenomenon may be, the trend is worrying since continued decrease in foliar P concentrations might lead to $\mathrm{P}$ deficiency, which was already observed on $22 \%$ of the studied plots. As already suggested by Ewald (2000) and Braun et al. (2010), P deficiency might lead to reduced growth and vitality of European beech forests. In addition, the susceptibility of trees to parasite infestation might be increased due to nutrient imbalances, including P (Flückiger and Braun 2003).

The difference between the large annual $\mathrm{P}$ requirement for forest growth and the small annual $\mathrm{P}$ input to forests emphasizes the importance of internal $\mathrm{P}$ recycling and conservation in maintaining high $\mathrm{P}$ availability. It also illustrates the possible impacts of large P removals by harvesting (Binkley and Fisher 2013). Due to increasing prices for P fertilizers and the fact that plant availability of $\mathrm{P}$ is not directly linked to total $\mathrm{P}$ stocks in soils or soil solution $\mathrm{P}$ concentrations, fertilization of forests should not be considered a viable option for 

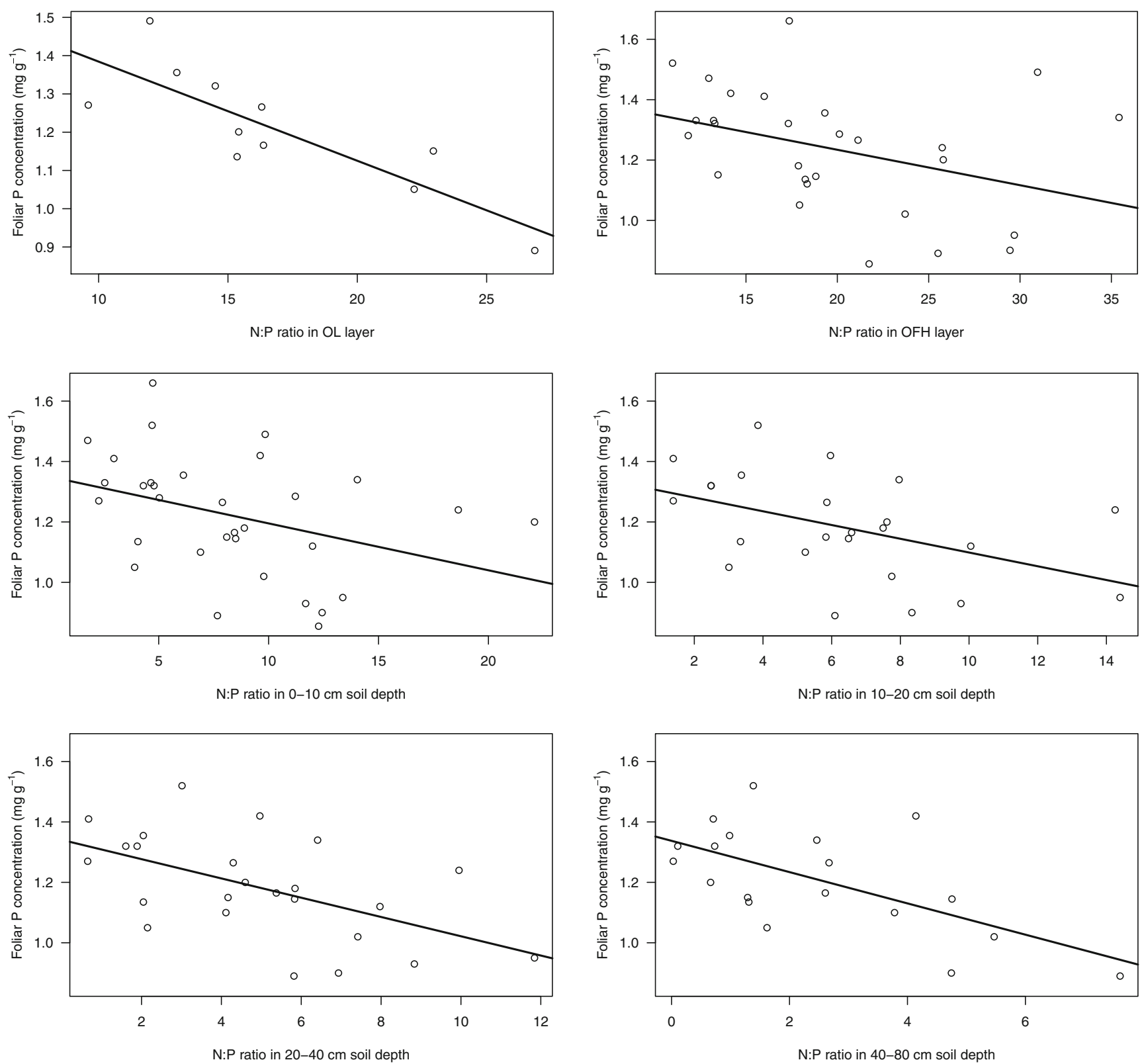

Fig. 7 Single linear regression between the trend in foliar $\mathrm{P}$ concentration and the forest floor and soil N/P ratio (OL: $y=-0.02 x+$ 1.64, $p=0.0014, R^{2}=0.70$; OFH: $y=-0.012 x+1.47, p=0.0478, R^{2}=$

counteracting $\mathrm{P}$ depletion. Instead, a better understanding of $\mathrm{P}$ levels and cycles in forest ecosystems, including the role of root dynamics and mycorrhizal symbioses, is needed as a basis for sustainable P management (Binkley and Fisher 2013). This is especially important now when more intensive biomass removals are applied in European forests to meet the growing demand for bioenergy (Matthews et al. 2014; Walmsley and Godbold 2010). Intensive biomass removals, such as whole-tree harvest, will reduce P reserves of forest ecosystems (Mann et al. 1988), while P demand of trees is already high due to increased growth as a consequence of anthropogenic $\mathrm{N}$ deposition and climate change.

0.14; 0-10 cm: $y=-0.01 x+1.35, p=0.0358, R^{2}=0.14 ; 10-20 \mathrm{~cm}: y=$ $-0.02 x+1.33, p=0.0225, R^{2}=0.21,20-40 \mathrm{~cm}: y=-0.03 x+1.34, p=$ $0.00561, R^{2}=0.30 ; 40-80 \mathrm{~cm}: y=-0.05 x+1.34, p=0.00425, R^{2}=0.39$ )

\section{Conclusion}

In all, our results show the value of a Europe-wide evaluation: While considering only individual plots may not reveal any trend due to too small datasets and high interannual variation, the evaluation of a Europe-wide dataset shows a clear decreasing trend in P nutrition of beech in Europe. Hence, further evaluations on a European scale combined with case studies and experiments are urgently needed in order to identify the drivers of the foliar P decrease. Especially, the role of mycorrhizal symbioses and their changes due to high levels of $\mathrm{N}$ deposition as well as the role of the climate and the 
consequences of climate change (e.g., prolonged growing season, increased fructification rates) in $\mathrm{P}$ nutrition of temperate forests should be investigated in future studies.

Acknowledgments The evaluation was based on data that are part of the UNECE ICP Forests Database (see www.icp-forests.org). In particular, data from Belgium (responsible institution: INBO), Croatia (Croatian Forest Research Institute), Czech Republic (VULHM), Denmark (Forest \& Landscape), France (RENECOFOR), Germany (Federal Ministry of Food and Agriculture), Hungary (State Forest Service), Italy (Conecofor), Luxembourg (Administration de la nature et des forêts, Service des forêts), Slovak Republic (National Forest Centre), Spain (General Directorate for Nature and Forest Policy), and Switzerland (WSL) were part of the analyses. Data collection was co-financed by the European Commission under regulations (EEC) No. 2158/86 and Forest Focus (EC) No. 2152/2003. We would especially like to thank the members of the ICP Forests Expert panel on foliage and litterfall for participating in the assessment of foliar data quality and its improvement, which allowed the evaluation of the presented data. Furthermore, we are grateful for the valuable comments of the editors and two anonymous referees on the manuscript.

Funding Data collection was co-financed by the European Commission under regulations (EEC) No. 2158/86 and Forest Focus (EC) No. $2152 / 2003$

\section{References}

Aber JD (1992) Nitrogen cycling and nitrogen saturation in temperate forest ecosystems. Trends Ecol Evol 7:220-224

Aber J, McDowell W, Nadelhoffer K, Magill A, Berntson G, Kamakea M, McNulty S, Currie W, Rustad L, Fernandez I (1998) Nitrogen saturation in temperate forest ecosystems. Biogeosciences 48: 921-934

Asp H, Bengtsson B, Jensén P (1991) Influence of aluminium on phosphorus and calcium localization in roots of beech (Fagus sylvatica). Physiol Plant 83:41-46. doi:10.1111/j.1399-3054.1991.tb01279.x

Binkley D, Fisher RF (2013) Ecology and management of forest soils, 4th edn. John Wiley \& Sons, Chichester

Braun S, Flückiger W (2013) Wie geht es unserem Wald? 29 Jahre Walddauerbeobachtung. Institut für Angewandte Pflanzenbiologie, Schönenbuch

Braun S, Rihm B, Schindler C, Flückiger W (1999) Growth of mature beech in relation to ozone and nitrogen deposition: an epidemiological approach. Water Air Soil Pollut 116:357-364. doi:10.1023/ A:1005209831728

Braun S, Thomas VFD, Quiring R, Flückiger W (2010) Does nitrogen deposition increase forest production? The role of phosphorus. Environ Pollut 158:2043-2052. doi:10.1016/j.envpol.2009.11.030

Conroy JP, Smillie RM, Küppers M, Bevege DI, Barlow EW (1986) Chlorophyll a fluorescence and photosynthetic and growth responses of Pinus radiata to phosphorus deficiency, drought stress, and high $\mathrm{CO}_{2}$. Plant Physiol 81:423-429

Cools N, Verschelde P, Quataert P, Mikkelsen JH, De Vos B (2006) Quality assurance and quality control. In: Forest soil analysis: 4th FSCC Interlaboratory comparison. INBO.R.2006.6. Forest Soil Coordinating Centre, Research Institute for Nature and Forest, Geraardsbergen

Cools N, De Vos B (2013) Forest soil: characterization, sampling, physical, and chemical analyses. In: Ferretti M, Fischer R (eds) Forest monitoring - methods for terrestrial investigations in Europe with an overview of North America and Asia. Elsevier, Oxford, pp 267-300

Cools N, Mikkelsen JH, De Vos B (2007) Quality assurance and quality control in forest soil analysis: 5th FSCC Interlaboratory comparison. INBO.R.2007.46. Forest Soil Coordinating Centre, Research Institute for Nature and Forest, Geraardsbergen

Danyagari G, Dang QL (2014) Soil temperature and phosphorus supply interactively affect physiological responses of white birch to $\mathrm{CO}_{2}$ elevation. Am J Plant Sci 5:219-229

De Vries W, Reinds GJ, van Kerkvoorde MS, Hendriks CMA, Leeters EEJM, Gross CP, Voogd JCH, Vel EM (2000) Intensive monitoring of forest ecosystems in Europe. EC, UNECE, Brussels, Geneva

Duquesnay A, Dupouey JL, Clement A, Ulrich E, LeTacon F (2000) Spatial and temporal variability of foliar mineral concentration in beech (Fagus sylvatica) stands in northeastern France. Tree Physiol 20:13-22

Ewald J (2000) Does phosphorus deficiency cause low vitality in European beech (Fagus sylvatica L.) in the Bavarian Alps? Forstwiss Cent 119:276-296

Ferretti M, Fischer R, Mues V, Granke O, Lorenz M (2010) Basic design principles for the ICP Forests Monitoring Networks. Manual Part II. Manual on methods and criteria for harmonized sampling, assessment, monitoring and analysis of the effects of air pollution on forests. UNECE, ICP Forests Programme Co-ordinating Centre, Hamburg. ISBN: 978-3-926301-03-1. http://www.icp-forests.org/ Manual.htm

Flückiger W, Braun S (1998) Nitrogen deposition in Swiss forests and its possible relevance for leaf nutrient status, parasite attacks and soil acidification. Environ Pollut 102:69-76. doi:10.1016/S02697491(98)80017-1

Flückiger W, Braun S (2003) Critical limits for nutrient concentrations and ratios for forest trees - a comment. In: Achermann B, Bobbink R (eds) Empirical critical loads for nitrogen. Swiss Agency for the Environment, Forests and Landscape (SAEFL), Berne, pp 273-280

FSCC (2006) Sampling and analysis of soil. Manual Part IIIa. In: Manual on methods and criteria for harmonized sampling, assessment, monitoring and analysis of the effects of air pollution on forests. UNECE, ICP Forests Programme Co-ordinating Centre, Hamburg. ISBN: 978-3-926301-03-1. http://www.icp-forests.org/Manual.htm

Fürst A (2014) 16th Needle/leaf interlaboratory comparison test 2013/2014. Technical Report QA-RFoliar14. Vienna

Galloway JN (2001) Acidification of the world: natural and anthropogenic. Water Air Soil Pollut 130:17-24. doi:10.1023/A:1012272431583

Gradowski T, Thomas SC (2006) Phosphorus limitation of sugar maple growth in central Ontario. For Ecol Manag 226:104-109

Gradowski T, Thomas SC (2008) Responses of Acer saccharum canopy trees and saplings to $\mathrm{P}, \mathrm{K}$ and lime additions under high $\mathrm{N}$ deposition. Tree Physiol 28:173-185. doi:10.1093/treephys/28.2.173

Haynes RJ (1982) Effects of liming on phosphate availability in acid soils. Plant Soil 68:289-308. doi:10.1007/BF02197935

Högberg P, Fan H, Qusit M, Binkley D, Tamm CO (2006) Tree growth and soil acidification in response to 30 years of experimental nitrogen loading on boreal forest. Glob Chang Biol 12:489-499. doi:10. $1111 / j .1365-2486.2006 .01102 . x$

Hothorn T, Bretz F, Westfall P (2008) Simultaneous inference in general parametric models. Biom J 50:346-363

Jansa J, Finlay R, Wallander H, Smith AF, Smith SE (2011) Role of mycorrhizal symbioses in phosphorus cycling. In: Bünemann EK, Oberson A, Frossard E (eds) Phosphorus in action. Biological processes in soil phosphorus cycling. Soil Biology 26:137-168

Jonard M, André F, Dambrine E, Ponette Q, Ulrich E (2009) Temporal trends in the foliar nutritional status of the French, Walloon and Luxembourg broad-leaved plots of forest monitoring. Ann For Sci 66:412

Khanna PK, Fortmann H, Meesenburg H, Eichhorn J, Meiwes KJ (2009) Biomass and element content of foliage and aboveground litterfall on the three long-term experimental beech sites: dynamics and 
significance. In: Brumme R, Khanna PK (eds) Functioning and management of European beech ecosystems, Ecological Studies 208. Springer, Berlin Heidelberg, pp 183-205. doi:10.1007/978-3642-00340-0_11

König N, Kowalska A, Brunialti G, Ferretti M, Clarke N, Cools N, Derome J, Derome K, De Vos B, Fuerst A, Jakovljevič T, Marchetto A, Mosello R, O'Dea P, Tartari A, Ulrich E (2010) Quality assurance and control in laboratories. Part XVI. In: Manual on methods and criteria for harmonized sampling, assessment, monitoring and analysis of the effects of air pollution on forests. UNECE, ICP Forests Programme Co-ordinating Centre, Hamburg. ISBN: 978-3-926301-03-1. http://www.icp-forests.org/ Manual.htm

Lorenz M, Granke O (2009) Deposition measurements and critical loads calculations: monitoring data, results and perspective. iFor Biogeosci For 2:11-14. doi:10.3832/ifor0478-002

Mann LK, Johnson DW, West DC, Cole DW, Hornbeck JW, Martin CW, Riekerk H, Smith CT, Swank WT, Tritton LM, van Lear DH (1988) Effects of whole-tree and stem-only clearcutting on postharvest hydrologic losses, nutrient capital, and regrowth. For Sci 34:412-428

Matthews R, Sokka L, Soimakallio S, Mortimer N, Rix J, Schelhaas MJ, Jenkins T, Hogan G, Mackie E, Morris A, Randle T (2014) Review of literature on biogenic carbon and life cycle assessment of forest bioenergy. Final Task 1 report, EU DG ENER project ENER/C1/ 427, Carbon impacts of biomass consumed in the EU. Forest Research, Farnham

Mellert KH, Göttlein A (2012) Comparison of new foliar nutrient thresholds derived from van den Burg's literature compilation with established central European references. Eur J For Res 131: 1461-1472

Mellert KH, Prietzel J, Straussberger R, Rehfuess KE (2004) Long-term nutritional trends of conifer stands in Europe: results from the RECOGNITION project. Eur J For Res 123:305-319

Mengel K, Kirkby EA (1982) Principles of plant nutrition, 3rd edn. International Potash Institute, Bern

Menzel A, Fabian P (1999) Growing season extended in Europe. Nature 397:659

Mohren GMJ, van den Burg J, Burger FW (1986) Phosphorus deficiency induced by nitrogen input in Douglas fir in The Netherlands. Plant Soil 95:191-200

Nihlgård B (1985) The ammonium hypothesis: an additional explanation to the forest dieback in Europe. Ambio 14:2-8. doi:10.2307/ 4313090

Nilsson LO, Wallander H (2003) Production of external mycelium by ectomycorrhizal fungi in a Norway spruce forest was reduced in response to nitrogen fertilization. New Phytol 158:409-416

Övergaard R, Gemmel P, Karlsson M (2007) Effects of weather conditions on mast year frequency in beech (Fagus sylvatica L.) in Sweden. Forest 80:555-565

Peñuelas J, Poulter B, Sardans J, Ciais P, van der Velde M, Bopp L, Boucher O, Godderis Y, Hinsinger P, Llusia J, Nardin E, Vicca S, Obersteiner M, Janssens IA (2013) Human-induced nitrogen-phosphorus imbalances alter natural and managed ecosystems across the globe. Nat Commun 4:2934. doi:10.1038/ncomms3934

Peuke AD, Rennenberg H (2004) Carbon, nitrogen, phosphorus, and sulphur concentration and partitioning in beech ecotypes (Fagus sylvatica L.): phosphorus most affected by drought. Trees 18:639 648. doi:10.1007/s00468-004-0335-x

Pinheiro J, Bates D, DebRoy S, Sarkar D, the R Development Core Team (2013) nlme: Linear and nonlinear mixed effects models. R package version 3.1-111

Piovesan G, Adams JM (2001) Masting behaviour in beech: linking reproduction and climatic variation. Can J Bot 79:1039-1047

Pretzsch H, Biber P, Schütze G, Uhl E, Rötzer T (2014) Forest stand growth dynamics in Central Europe have accelerated since 1870. Nat Commun 5:4967. doi:10.1038/ncomms5967
Prietzel J, Stetter U (2010) Long-term trends of phosphorus nutrition and topsoil phosphorus stocks in unfertilized and fertilized Scots pine (Pinus sylvestris) stands at two sites in Southern Germany. For Ecol Manag 259:1141-1150

R Core Team (2013). R: A language and environment for statistical computing. R Foundation for Statistical Computing, Vienna. http:// www.R-project.org/

Raghothama KG (1999) Phosphate acquisition. Annu Rev Plant Biol 50: 665-693

Rautio P, Fürst A (2013) Tree foliage: sampling and chemical analyses. In: Ferretti M, Fischer R (eds) Forest monitoring - methods for terrestrial investigations in Europe with an overview of North America and Asia. Developments in environmental science. Elsevier, Oxford, pp 223-236

Rautio P, Fürst A, Stefan K, et al. (2010) Sampling and Analysis of Needles and Leaves. Manual Part XII. In: Manual on methods and criteria for harmonized sampling, assessment, monitoring and analysis of the effects of air pollution on forests, UNECE, ICP Forests Programme Co-ordinating Centre, Hamburg. ISBN: 978-3-92630103-1. http://www.icp-forests.org/Manual.htm

Reich PB, Oleksyn J, Wright IJ (2009) Leaf phosphorus influences the photosynthesis-nitrogen relation: a cross-biome analysis of 314 species. Oecologia 160:207-212

Sardans J, Rivas-Ubach A, Peñuelas J (2011) The C:N:P stoichiometry of organisms and ecosystems in a changing world: a review and perspectives. Perspect Plant Ecol Evol Syst 14:33-47

Spiecker H (1999) Overview of recent growth trends in European forests. Water Air Soil Pollut 116:33-46. doi:10.1023 A:1005205515952

Stefan K, Fürst A, Hacker R, Bartels U (1997) Forest foliar condition in Europe. EC, UNECE, Brussels, Geneva

Trichet P, Bakker MR, Augusto L, Alazard P, Merzeau D, Saur E (2009) Fifty years of fertilization experiments on Pinus pinaster in Southwest France: the importance of phosphorus as a fertilizer. For Sci 55:390-402

Tucker CJ, Slayback DA, Pinzon JE, Los SO, Myneni RB, Taylor MG (2001) Higher northern latitude normalized difference vegetation index and growing season trends from 1982 to 1999. Int J Biometeorol 45:184-190

Vitousek PM, Porder S, Houlton BZ, Chadwick OA (2010) Terrestrial phosphorus limitation: mechanisms, implications, and nitrogenphosphorus interactions. Ecol Appl 20:5-15

Waldrop MP, Zak DR, Sinsabaugh RL (2004) Microbial community response to nitrogen deposition in northern forest ecosystems. Soil Biol Biochem 36:1443-1451. doi:10.1016/j. soilbio.2004.04.023

Walmsley JD, Godbold DL (2010) Stump harvesting for bioenergy-a review of the environmental impacts. Forest 83:17-38. doi:10.1093/ forestry/cpp 028

Wardle DA, Walker LR, Bardgett RD (2004) Ecosystem properties and forest decline in contrasting long-term chronosequences. Science 305:509-513

Zanella A, Englisch M, Jabiol B, Katzensteiner K, de Waal R, Hager H, van Delft B, Graefe U, Brun JJ, Chersich S, Broll G, Kolb E, Baier R, Baritz R, Langohr R, Cools N, Wresowar M, Milbert G, Ponge JF (2006) Towards a common humus form classification, a first European approach: few generic top soil references as functional units. Poster presented at the 18th World Congress of Soil Science, Philadelphia

Zanella A, Jabiol B, Ponge JF, Sartori G, De Waal R, Van Delft B, Graefe U, Cools N, Katzensteiner K, Hager H, Englisch M (2011) A European morpho-functional classification of humus forms. Geoderma 164:138-145

Zeileis A (2004) Econometric computing with HC and HAC covariance matrix estimators. J Stat Softw 11:1-17. http://www.jstatsoft.org/ v11/i10/ 